\title{
PERSPEKTIVE EVROPSKE REGIONALNE INTEGRACIJE I VALUTNE ZONE
}

\author{
Slobodan N. Bracanović* \\ Ekonomski fakultet Priština, Kosovska Mitrovica
}

Evropska integracija zemalja sa jedinstvenom valutnom zonom je u krizi i sa neizvjesnim perspektivama. Pojedine zemlje nagovještavaju istupanje iz EU i iz valutne zone. Projekat EU i zajedničke monete ocjenjuje se nepovoljno, jer nije podržan svim neophodnim institucijama. Ekonomska i politička integracija nisu usklađene. Zemlje članice gube suverenitet u određivanju kamatne stope i deviznog kursa.

Ključne reči: Evropa, integracija, ciljevi, ekonomija, politika, moneta, kriza, ishod

\section{Uvod}

Evropski region se nalazi u društveno-ekonomskoj, organizacionoj i E političkoj krizi. Krizni tokovi različitom težinom pogađaju pojedine zemlje u regionu. Prisutni su i separatistički i secesionistički pokreti (npr. KataIonija, područje koje okružuje Barcelonu u Španiji). Aktuelne su tendencije napuštanja Evropske unije (referendumsko izjašnjenje stanovnika Velike Britanije). Ekonomski indikatori u silaznom su trendu (bruto domaći proizvod po stanovniku niži je u upoređivanju sa nivoom prije izbijanja ekonomsko finansijske krize 2007/8), visoka je i nezaposlenost (u Španiji stopa iznosi 20\% i polovina mladih ljudi bez radnog je angažovanja). Javlja se emigracija stanovništva u traganju za zapošljavanjem. Jedan od pokazatelja kvaliteta uspješnosti i efikasnosti ekonomije i intenzivnog razvoja je i dinamičan privredni rast (sa visokom produktivnošću rada i zaposlenošću). Evropska kretanja, međutim, u suprotnom su pravcu u najnovijem periodu.

Tokom prethodnog perioda (1989/92. god.) uvedena je jedinstvena zajednička evropska valuta (evro). Ovaj proces nije praćen i formiranjem adekvatnih institucija (ustanova) koje bi podržavale održavanje i funkcionisanje valute. Sa ovim u vezi tvrdi se da fiksiranje kursa, vrijednosti valute određene zemlje za drugu valutu (ili pojedini proizvod), tj. čvrsti devizni kurs, povezuje se sa tokovima recesije, depresije i krize.

Govori se, uporedno i o uvođenju zlatnog standarda (krajem 19. vijeka). Naime; svaka zemlja vezivala je vrijednost sopstvene novčane jedinice za zlato sa međusobnom povezanošću. Rijetkost zlata, a nepostojanjem novih zlatnih nalazišta, dovodi do silaznog trenda cijena (standardnih) proizvoda (roba) u upoređivanju sa zlatom (u današnje vrije-

*slobodan.bracanovic@pr.ac.rs 
me ova pojava određuje se kao deflacija). Novac, u praksi, postaje vredniji. Zlatni standard (načelo, princip) označava se i da je pojačao i odužio trajanje Velike ekonomske krize kapitalističkog društveno-ekonomskog sistema (1929-33). Zemlje koje su prije odustale od zlatnog standarda, brže su i izašle iz krize. Zaključuje se da je zlatni standard bio greška bez ikakve ozbiljnije i široke namjere ponovnog uvođenja.

Evropska unija uvodi jedinstvenu valutu oblikujući nefleksibilnost, neprilagodljivost, krutost, koju je svojevremeno i zlatni standard (potpuno zlatno pokriće) nametao cjelokupnom svijetu. Ukazuje se na nužnost dubokih budućih strukturnih preobražaja (prividnih, pojavnih, „kozmetičkih“ reformi), za koje je neophodno državno, društveno i političko jedinstvo, usklađenost i kohezija. Tokom proteklog perioda (2015) Evropska unija (sa 28 članica i više od pola milijarde stanovnika), nominalno prema veličini druga je ekonomija svijetu (sa bruto domaćim proizvodom više od 16 biliona dolara, neznatno nižim od nivoa koji se istodobno, zvanično, prikazuje ostvarenim u SAD). Usljed oscilacija valutnog kursa (evra u poređenju sa dolarom) relativna veličina ostvarenog bruto domaćeg proizvoda varira (po tekućem, momentalnom kursu). U ranije vrijeme (2014), Evropska unija je nominalno vodeća ekonomska integraciona grupacija zemalja u svijetu. Unutar Evropske unije, određeni broj članica (19) uvodi prihvaćenu jedinstvenu zajedničku valutu (evro). Ideje o međusobnom vezivanju svojih valuta i uvođenju jedinstvene valute (evro zone) manifestovale su se znatno ranije (1989/92). Formalni sporazum o Evropskoj uniji poznat je kao „Mastrihtski ugovor" (1992). Nakon ekonomsko-finansijske krize u SAD (2007/8) krizni nepovoljni učinci („demonstracionim“, „domino“, „bilijar“, „uzor“ efektom) prelivaju se i na Evropsku uniju i druge zemlje. Tvrdi se da su se SAD u velikoj mjeri „oporavile od krize“, ali blijedo, anemično i zakasnelo dok se Evropa i prvenstveno evrozona nalazi u stanju faze stagnacije. [13; 9-11]

\section{Ekonomsko stanje i valutne perspektive}

Evropske integracije i uvođenje jedinstvene valute predstavlja integracioni i valutni eksperiment. U oblasti ekonomske nauke ne primjenjuju se metodi eksperimenata laboratorijskog tipa kako je uporedno moguće u prirodnim naukama. Nužno je, međutim, odvijanje eksperimentalnih istraživanja i analiza ideja i idejnih postulata sa prirodnim, naučnim, političkim i dr. determinantama. Evropska unija u cjelini i posebno valuta (valutna zona) čine spoj ideja, ideologije, politike i ekonomije. Realizacijom eksperimenta nastala je složena neravnoteža stanja.

Ekonomski procesi integrisanja nisu usklađeni sa tokovima političke integracije. Program i projekat Evropske integracije, kao i evrozone, ishodišnih je stremljenja postizanja i dostizanja višeg nivoa političko ekonomske integracije. Težilo se favorizovanju djelovanja nesputanih i nelimitiranih tržišta, kao stabilnih, ravnotežnih i efikasnih. Isto tako, nastojalo se zaustavljanju mehanizama, instrumenata i postupaka regulacije i preokretanja u suprotnom pravcu i smjeru deregulacije. Projekat jedinstvene valute u okvirima je određenih ideja i ideologija ciljno-interesnih grupa i grupacija. Ekonomski integracioni procesi, mogu da dođu na pogrešne kolosjeke u stanju i situacijama kada određene ekonomske teorije i usmjerenja, determinisane ideologijom, grupacijskim ciljevima i interesima umjesto istinskom ekonomskom naukom, metodima i dokazivanjima, kreiraju i kanališu politič- 
ko odlučivanje. [13; 11-14] Sa ovim dolazi do savremenog izražaja i sloj „plutokratije“, tj. vladavine finansijskog kapitala kojim se realno ostvaruje i politička moć.

Ideje doktrine neoliberalizma i tzv. „Vašingtonskog kosenzusa“ (nametanje uslova privredno manje razvijenim zemljama) determinisale su politiku, strategije i institucije u novijem periodu. Istovjetne ili analogne ideje djelovale su i u kreiranju programa i projekta evropske integracije i oblikovanja valutne zone tj. uvođenjem zajedničke valute.

Evropska integraciona grupacija primenjuje deklarativno „politiku štednje“, mada je suštinski riječ o oštrim, rigoroznim, ekonomskim restrikcijama ličnih primanja. Nastoji se krutim i rigidnim budžetskim gabaritima umanjivati državna potrošnja i preko najnužnijih okvira.

Ekonomiju i politiku (i pored nastojanja) nije moguće posmatrati potpuno izolovano, izvještačeno, odvojeno; mada teško usklađeno funkcionišu ove djelatnosti i objektivna realnost stvarnosti, često su konfliktnosti ciljeva, interesa i zadataka. Tvrdi se da je „ekonomska globalizacija" bila dinamičnija od političkog trenda.[13; 15]

Ekonomski istraživači i analitičari primjenjuju statističku analizu i, čestu, argumentovanost pokazateljima koji metodološki predstavljaju prosječne (i srednje) veličine, kao npr. kod kretanja važnih ekonomskih kategorija (bruto i neto domaćeg proizvoda i nacionalnog dohotka, akumulacije, dobiti, relativno po stanovniku). [2; 336-345] Postoji mogućnost da tendencije bruto domaćeg proizvoda kreću se uzlaznom linijom, a da većina stanovništva egzistira na nižem nivou (u upoređivanju sa prethodnim stanjem). Pored formiranja osnovnih ekonomskih kategorija (proizvoda tj. prihoda, dohotka, akumulacije, dobiti, profita i dr), bitno je i pitanje raspodjele i preraspodjele ostvarenih veličina. Isto tako bitna je ukupnost (masa) ekonomskih kategorija ali i veličina prema stanovniku.

Socioekonomsko raslojavanje, nejednakosti, rascjepi, diobe, podjele neminovno djeluju na ekonomske učinke, [4;6;8] kao i na stanje cjelokupne „demokratije“. Neolieberalni ekonomski program doveo je, umjesto značajnijeg dinamiziranja privrednog rasta, do porasta raslojavanja. Polazi se od pretpostavke (hipoteze) da je: evropska integracija i evro zona, pojačavala raskole u smislu da ekonomski razvijenije zemlje još se više udaljavaju od privredno nerazvijenih, nedovoljno i manje razvijenih zemlja. Ova okolnost odnosi se na aspekt između zemalja, ali i na okvire (gabarite) unutar zemalja, posebno evrozone. Umanjeni su i efekti prediintegracionog stepena jaza.

Državne mjere restrikcije, koje se deklarativno označavaju kao „„̌tednja“, nepovoljno se odražavaju na lični standard stanovnika sa niskim, nižim i srednjim (i prosječnim) prihodima. Visoka nezaposlenost dovodi i do pritiska na kretanje nadnica.

Uviđa se da deregulacija i tržišna privreda nije ravnotežna, harmonična, stabilna i, sama za sebe, efikasna. [11;12] Krize su imanentna svojstva od nastanka kapitalističkog društveno-ekonomskog sistema kao i oštri rast raslojavanja.[13; 15-17]

Standardni metodi i modeli u ekonomskoj nauci pretpostavljaju postojanje stanja ravnoteže. Postoje dinamički, stohastički modeli opšte ravnoteže kao polazne pretpostavke. Kada privreda počinje kretanje u silaznom trendu, u skorijem vremenskom intervalu, hipotetički, ponovo dolazi u ravnotežno, tj. stabilno stanje. Kod ovog aspekta ne tumači se i ne eksplicira kako i da li je ova ravnoteža faktički ostvarena u složenoj praksi privrednog života. Privrede se često ne kreću u smjeru približavanja, uravnotežavanja, usklađivanja, konvergencije (već trendom divergencije). 
Finansijski sistemi i tržišta ukoliko se ne regulišu i ne usmjeravaju, tj. ukoliko su u velikoj mjeri ili potpuno decentralizovani i njima se ne upravlja mogu da uzrokuju ekonomsku nestabilnost, debalanse i neravnotežu. Ovo je dokazala ekonomska, hipotekarna i finansijska kriza manifestovana u SAD (2007/8. god.) koja se zatim „talasima“ prelivala na ostale evropske, zapadne i pojedine druge zemlje i rejone.

Sa šireg aspekta, neoliberalna ekonomska doktrina posebno je dolazila do izražaja u završnoj deceniji prethodnog vijeka kada je i došlo do formiranja evropske integracije zemalja i sa idejom o valutnoj zoni („Mastrihtskim ugovorom“, 1992). Preciznije, jedinstvena evropska valuta otpočela je funkcionisanje kasnije (države evrozone međusobno su vezale svoje valute 1999, a evro je pušten u opticaj 2002). Sa neoliberalnom teorijom povezana je i konvencionalna monetarna teorija i ekonomija koja se u ekstremnom tumačenju svodi na "leze fer" pristup. Monetarna doktrina i ekonomija posmatra se u komparaciji sa realnom (proizvodno-uslužnom) ekonomijom. Nedostaci monetarne škole predmet su ekonomskih istraživanja. [13;18-29]

Ekonomski ciljevi nužni su za postizanje širih i kompleksnijih vrijednosti i ciljeva. „Blagostanje“ pojedinaca, kolektiva, grupa, grupacija i društva kao cjeline nije uslovljeno jedino veličinom ekonomske kategorije bruto domaćeg (društvenog) proizvoda. Postoji kompleksniji obuhvat vrijednosti sa socijalnim aspektima i indikatorima, skladom, balansom i kohezijom, povjerenjem u društvene i državne ustanove, istinsku, ekonomsku, političku i društvenu demokratiju i sl. [2; 329-357] Evropska jedinstvena valuta dijalektički i strukturno logično, samo je sredstvo, a ne cilj optimiziranja, projektovanih, ekonomskih rezultata i društveno-političke harmonije, usklađivanja i povezivanja širom prostora evropskog kontinenta. Međutim, često sredstva postaju ciljevi (i obratno) ili ne korespondiraju sa ciljevima.

Finansijski ciljni interesi naglašeno često favorizovani su u razvijanju ekonomskih povezanosti i tokova integracija. Ideje, ideje vodilje, ideologije, ideali, motivacija interesne grupe i grupacije oblikuju i preoblikuju ekonomske i ostale procese, strukture, trendove, tendencije, prikladne i primjerene malom broju (opsegu) najbogatijih, moćnih pojedinaca ali najčešće pogađaju najveće mase stanovništva. $[13,19]$

Političari, a ne ekonomisti, determinišu odlučivanje i odluke sa stanovišta prevashodnog postizanja političkog profita u kratkom i kraćem roku. Ove aktivnosti mogu ostvarivati teške dugoročne ekonomske i društvene posljedice. Evropska unija i posebno evro zona mogle bi da funkcionišu i u stanjima kad ekonomski jače, razvijenije, bogatije zemlje pružaju pomoć slabijim, manje razvijenim, siromašnijim. Evropska monetarna unija nužno mora da računa sa podjelom rizičnosti.

Tokom prethodnog vremena (za pola vijeka) najvažnije društveno dešavanje, za većinu stanovnika evropskog kontinenta, evropski je program i projekat integracije i budućeg uspješnijeg povezivanja. Mogućnost propadanja evropskog projekta i ne shvata se ozbiljno. Ali, ukazuje se da je valutni sistem (evra) u krizi i formiranju nepovoljnih ekonomskopolitičkih učinaka. Ističe se da sadašnji sistem i sa najnovijim reformskim mjerama i aktivnostima nije moguće održavati u dugom vremenskom horizontu bez stvaranja enormnih rashoda za najveći broj stanovnika evropskog regionalnog prostora. Ovi rashodi kompleksniji su od ekonomskih troškova (mada su ekonomski učinci jedni od bitnih ishodišta društvenih „deformacija“). Konkretnije, dolazi i do: anomalija, potresa, „lomova“, „grčeva“, „entropije“ sistema. Javljaju se nepredviđeni udari u društvu, privredi, politici (ekstremni pokreti i sl.). 


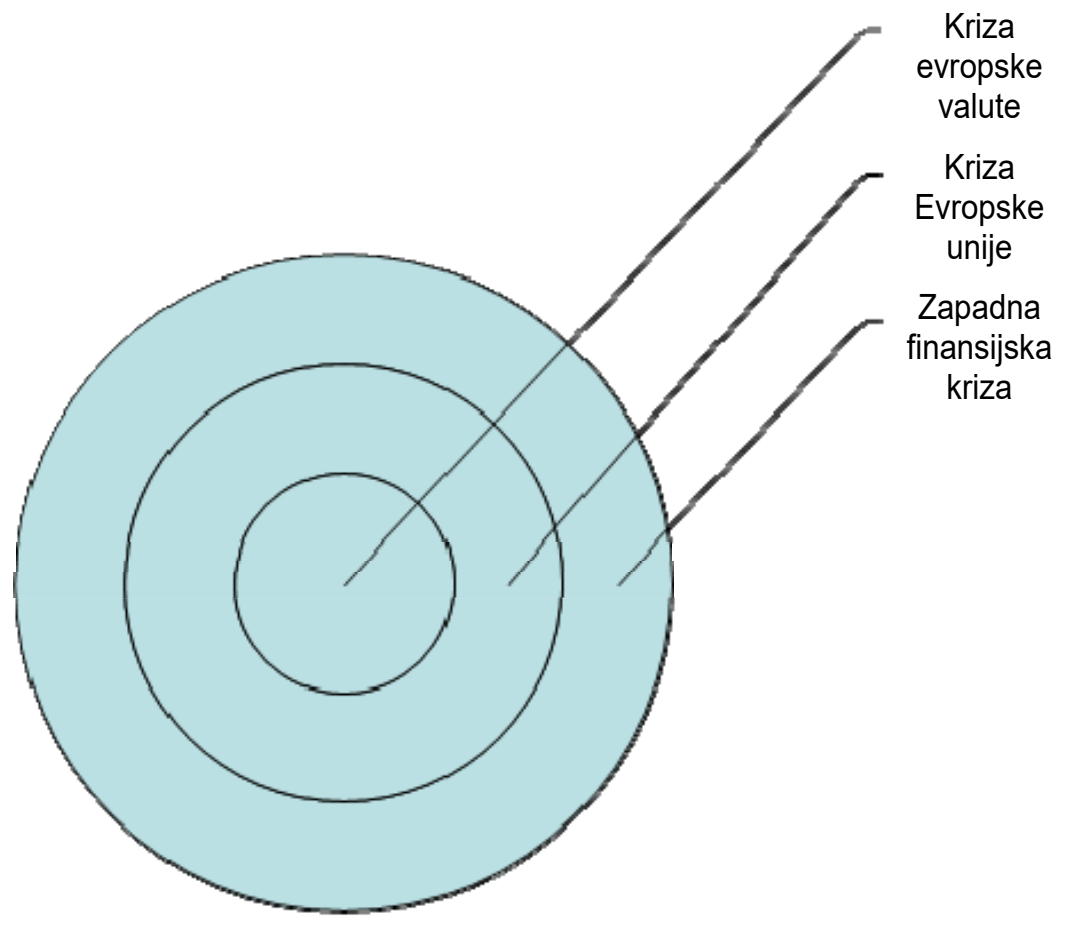

Dijagram 1 - Talasasta prelivanja kriznih, ekonomskih, finansijskih i ostalih efekata

Ekonomska, hipotekarna i finansijska kriza manifestovana u SAD (2007/8) transformisala se u krizu evropske integracije u cjelini i posebno valutne zone i jedinstvene valute. Ovo su efekti prelivanja („domino“, „bilijar“ efekat i sl.).

$U$ literaturi se navodi da se kod privredno nerazvijenih i nedovoljno razvijenih, „siromašnih" zemalja, nije dovoljno jedino održavati niži, ili niski budžetski deficit i zaduženost (prema BDP-u), za približavanje (,konvergenciju“) privredno razvijenim i „bogatim“ zemljama. Međutim, budžetski deficiti i javna i spoljna zaduženost, težak su (i jedan od najtežih) društveno-ekonomski problem. Pored ovog, ukazuje se, da je Evropa nedvosmisleno pogriješila u nastojanjima postizanja integrisanog kontinenta posredstvom monetarne unije i monolitne valutne (evro) zone. [13;20] Nužna je „reforma“ politike, strategija, procesa, strukture, postupaka evrozone. Monetarne konture i obrisi nisu nepromjenljivi (metafizički) poput prirodnih zakona. Neophodne su u cilju i svrsi sagledavanja mogućnosti održavanja i perspektiva Evropske integracije, transformisane i nove norme i pravila aktivnosti ekonomije i institucija i ne jedino pravila, tehnike, postupci i procedure, već i kvalitet procesa i dubokih strukturnih preobražaja. Isto tako, racionalna je rekonfiguracija vizije vrijednosti i ciljeva koji je već postojao, ili i još postoji. [9] Postoje zemlje Evropske unije koje su izrazito u krizi (Portugalija, Španija, Grčka, Irska). Sa složenim društvenoekonomskim problemima suočavaju se druge zemlje (Italija, Francuska, Finska). Indika- 
tivne su i zemlje snažne sa spoljnog aspekta (Njemačka i pojedine zemlje Beneluksa, tj. Holandija i Belgija). Moguće je i istupanje Grčke iz Evrozone. Na primjeru Grčke navode se veze međuzavisnosti: ekonomije, politike, bankarskog i marketinškog sloja. Pored ovog, Velika Britanija (referendumski) izglasala je istupanje iz Evropske integracione grupacije zemalja. Ekonomska i finansijska integracija, dileme, pitanja, suštinski su bitna za izučavanje ukupne integracione i valutne problematike. [13;20-58]

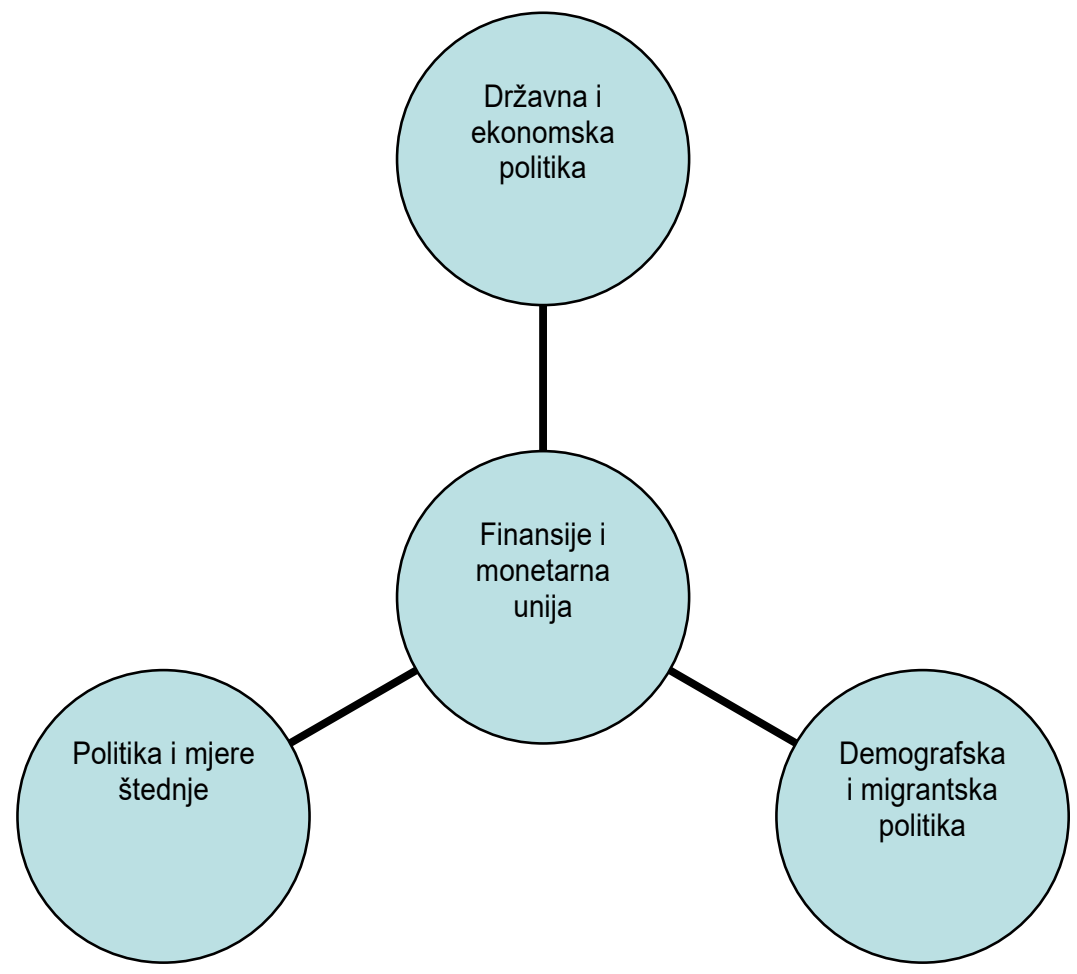

Dijagram 2 - Osnovni aspekti integracione, državne, ekonomske i finansijske politike

Politika „štednje“ predstavlja domen i domet oštrih, krutih, rigoroznih restrikcija: javne, socijalne i lične potrošnje. Preciznije, štednju shvatam u drugačijem smislu, kada realno postoje finansijska sredstva koja se mogu uštedjeti (akumulirati) bez ozbiljnih udara na nužne okvire (gabarite) javne potrošnje i ličnog, životnog i opšteg standarda stanovništva. Dolazi, posljedično, do socijalnih poremećaja, potresa i lomova, naročito u pojedinim zemljama (Grčka i dr). Isto tako, aktuelna je, još uvijek i migrantska politika i kriza, tj. masovni prilivi izbjeglica iz područja konfliktnosti, sukoba i ratom zahvaćenih (afričkih i azijskih) područja. Osim ovog, postoje realne prijetnje kao i faktičko izvršenje terorističkim napadima na bitne strateške lokacije i evropska, urbana, središta (Pariz, Brisel, London i dr.) 
Evropska unija suočava se sa mnogobrojnim socioekonomskim problemima (silaznim trendom bruto domaćeg proizvoda po srednjoročnoj stopi od $0,25 \%$, visokom opštom stopom nezaposlenosti od više od $10 \%$ i, naročito, dvostruko višom kod mladih školovanjem za rad osposobljenih ljudi i, posljedično, masovnom emigracijom stanovništva iz pojedinih zemalja u potrazi za radnim angažovanjem, zaduženošću pojedinih država iznad graničnika 60\% BDP-a i dr). Projicira se i koncipira evropska budućnost sa usporenim privrednim rastom i razvojem i umanjenijim ličnim, životnim i opštim standardom građana (kod više ili manje pesimističkih varijanti).

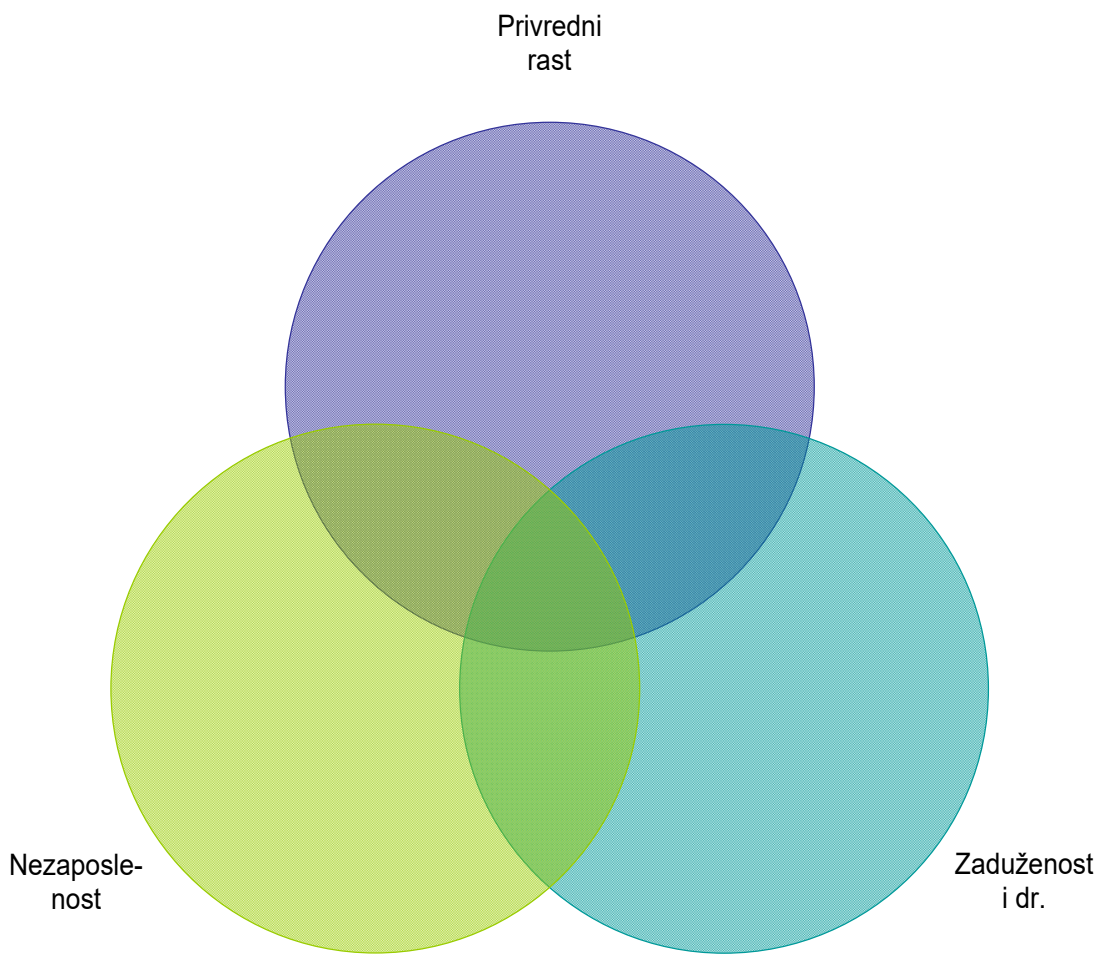

Dijagram 3 - Najteži, najsloženiji društveno ekonomski problemi evropske integracije

Ekonomski procesi i kretanja uzrokuju i političke učinke (kao i obratno). „Noseći stubovi" Evrope nakon perioda Hladnog rata postaju klimavi. Manifestuju se separatistički, secesionistički pokreti (Španija, Italija, Velika Britanija i dr). Govori se i o formiranju Evropske unije (1992) kao najvećem postignuću Evrope (druge polovine 20. vijeka) ali veoma je neizvjesna dugoročna održivost ove integracije. Ukazuje se u literaturi na neuspjehe i promašaje evropske valutne zone (evra). Ekonomija i pored svih neusklađenosti povezana je sa politikom. Politika može da sprečava ekonomske tokove koji bi bili uslov uspješnosti jedinstvene evropske valute. 


\section{Srbija i ekonomske kategorije u evropskoj valuti}

Kretanja bruto društvenog proizvoda iskazana u evrima vrlo su indikativna.

Tabela 1 - Tendencije bruto društvenog proizvoda u Srbiji

\begin{tabular}{|c|l|r|r|r|r|r|}
\hline R. br. & \multicolumn{1}{|c|}{ Elementi } & \multicolumn{1}{c|}{2001.} & \multicolumn{1}{c|}{2006.} & \multicolumn{1}{c|}{2011.} & \multicolumn{1}{c|}{2016.} & \multicolumn{1}{c|}{ Rast (\%) } \\
\hline 1. & BDP (milioni evra) & $13.805,5$ & $24.434,6$ & $33.423,8$ & $34.616,6$ & 6,33 \\
\hline 2. & Po stanovniku (evr.) & 1.840 & 3.297 & 4.619 & 4.904 & 6,77 \\
\hline 3. & Realni rast (\%) & 5,0 & 4,9 & 1,4 & 2,8 & $-3,79$ \\
\hline
\end{tabular}

Izvor: Ministarstvo finansija Republike Srbije [decembar, 2017], „Bilten javnih finansija“, Beograd, str. 15-16.

Napomena: Procijenjeni realni rast BDP-a (od strane MFIN) za 2017. god., iznosi 2,0\%.

Uočava se znatno dinamičan rast ekonomske kategorije (mase) BDP-a u Srbiji u proteklom dugoročnom periodu. Rast relativnih indikatori po stanovniku viši je i ovo je moguće tumačiti, pored obuhvatnosti i vjerodostojnosti statističkih pokazatelja, i demografskim kretanjima (tj. smanjivanjem stanovništva) i kretanjima, mobilnošću, tj. emigracijom stanovništva (radne snage) iz države. Međutim, realni rast veličine BDP-a znatno je niži (isključujući i eliminišući inflatorne i ostale uticaje, koji deformišu stvarnu veličinu ekonomske kategorije). Neophodno je istaći da ova kategorija nije i jedina, jer postoje drugi i kompleksni socijalni pokazatelji sa važnom ulogom u sagledavanju nivoa kvaliteta života (indeks humanog razvoja, HDI; „Gini“ koeficijenat nejednakosti u raspodjeli i dr). [2; 329-357]

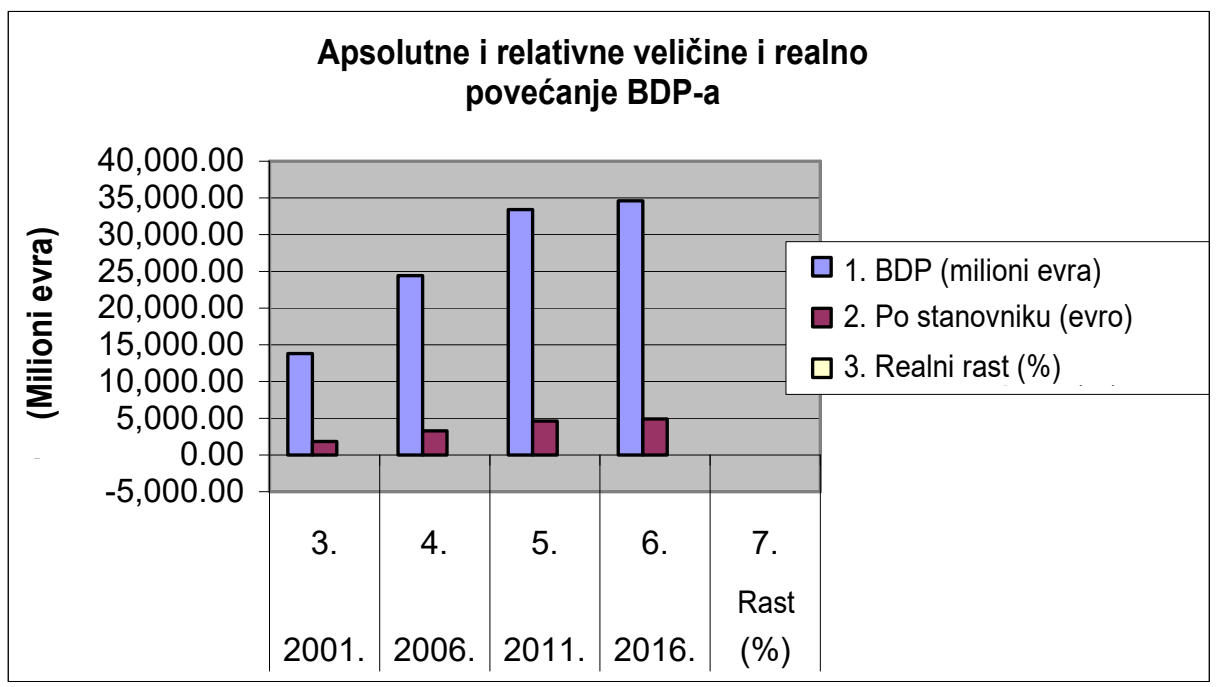

Grafikon 1 - Tabelarni numerički indikatori BDP-a

Polazeći od značaja prikazaćemo trendove inostranih (direktnih, neto) ulaganja. 
Vojnoekonomski pregled

Tabela 2 - Volumen i opseg stranih direktnih neto investicija u Srbiji (Milioni evra)

\begin{tabular}{|c|l|r|r|r|r|r|}
\hline R. br. & \multicolumn{1}{|c|}{ Elementi } & \multicolumn{1}{|c|}{2001.} & \multicolumn{1}{c|}{2006.} & \multicolumn{1}{c|}{2011.} & \multicolumn{1}{c|}{2016.} & \multicolumn{1}{c|}{ Rast (\%) } \\
\hline 1. & SDI & 184,1 & $3.322,6$ & $3.319,6$ & $1.899,2$ & 16,84 \\
\hline 2. & $\%$ BDP-a & 1,3 & 13,6 & 9,9 & 5,5 & 10,09 \\
\hline
\end{tabular}

Izvor: Isto, str. 15-16.

Napomena: SDI za prva tri kvartala 2017. iznose 2.288,2 miliona evra; 7,1\% BDP-a.

Konstatuje se dinamičan porast stranih direktnih investicija, mada su znatne oscilacije u apsolutnom obimu tih ulaganja. Učešće u strukturi BDP-a, međutim, nižeg je nivoa i, isto tako, fluktuirajućeg trenda. Neophodno je istaći $[1,125]$ da je strani ulagač motivisan jedino sopstvenim profitnim interesima, maksimizacijom profita. Od značaja su domaća ulaganja i investicioni institucionalni fondovi, investitori.[3]

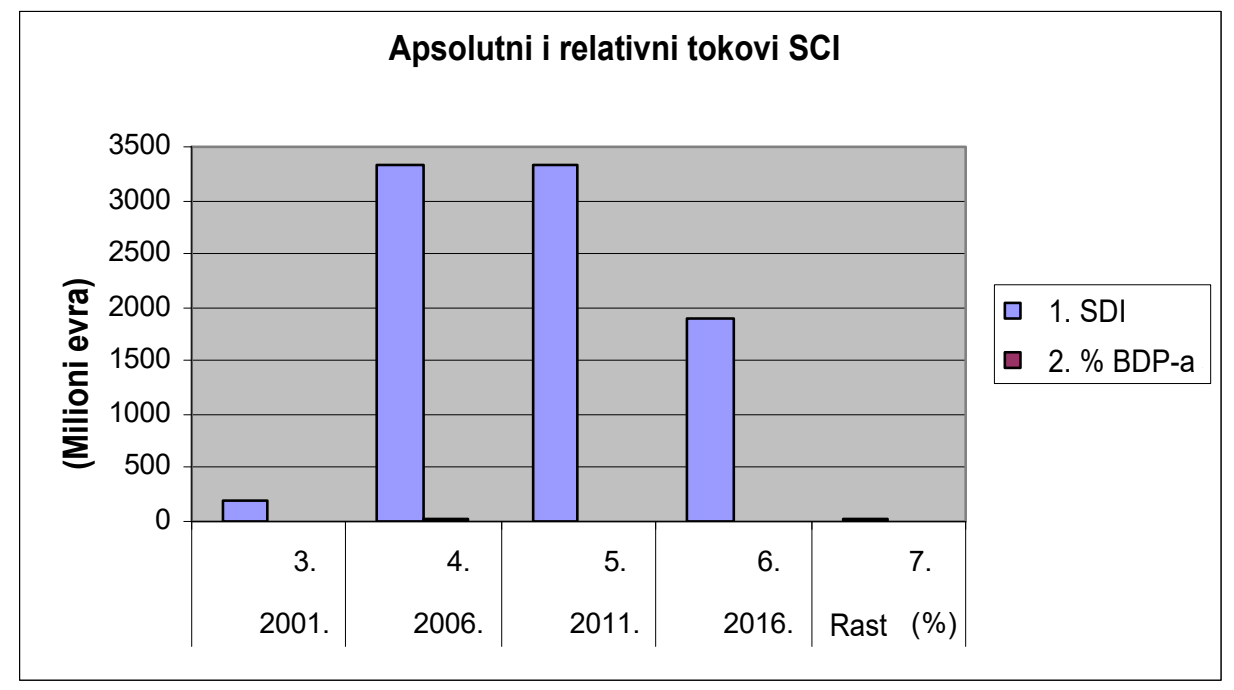

Grafikon 2 - Kvantitativni investicioni parametri

Spoljna zaduženost jedan je od akutnih, najtežih privrednih problema Srbije.

Tabela 3 - Dugoročno kretanje veličine ostvarenog spoljnog duga Srbije (Milioni evra)

\begin{tabular}{|c|l|r|r|r|r|r|}
\hline R. br. & Elementi & \multicolumn{1}{|c|}{2001.} & \multicolumn{1}{c|}{2006.} & \multicolumn{1}{c|}{2011.} & \multicolumn{1}{c|}{2016.} & \multicolumn{1}{c|}{ Rast (\%) } \\
\hline 1. & Spoljni dug & 11.255 & 14.291 & $24.123,5$ & 26.493 & 5,86 \\
\hline 2. & $\%$ BDP-a & 81,5 & 58,5 & 72,2 & 76,5 & $-0,41$ \\
\hline
\end{tabular}

Izvor: Isto, str. 15-16.

Napomena: Spoljni dug za devet mjeseci 2017. je 26.032,6 miliona evra; 72,4\% BDP-a. 
Dugoročni rast spoljne zaduženosti je izražen i veliko opterećenje države i privrede. Zaduživanje u cilju otplate već dospjelih dugova ekonomski nije prihvatljivo.

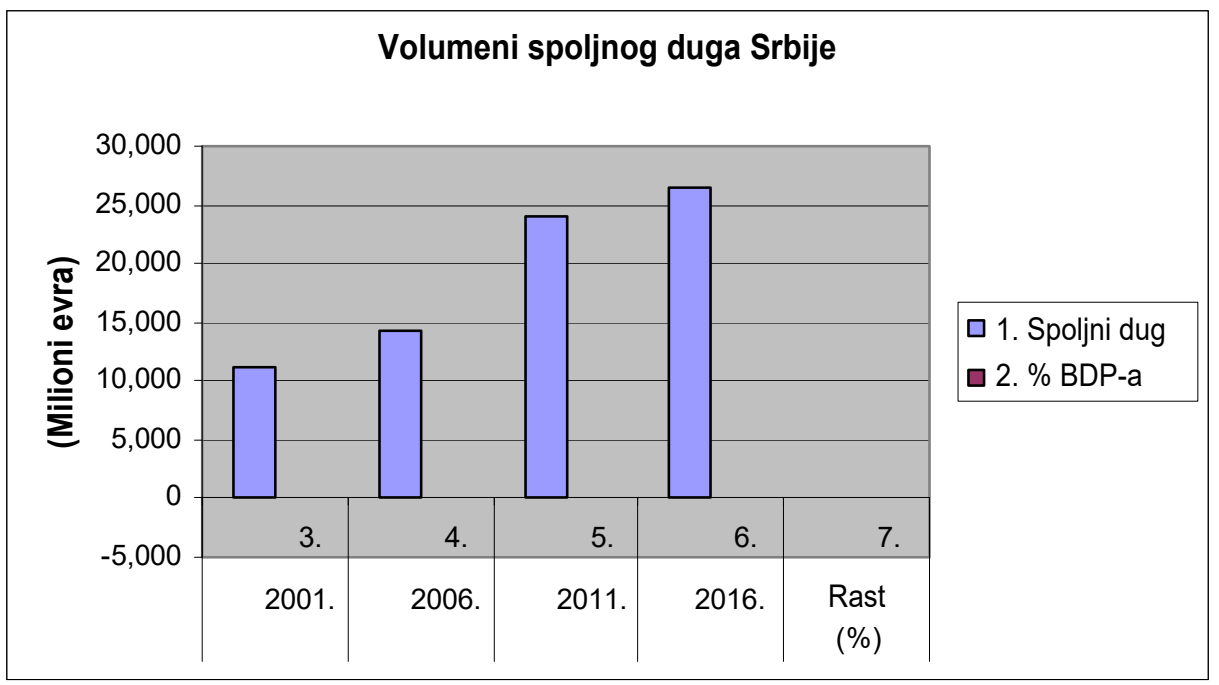

Grafikon 3 - Statistički pokazatelji nivoa spoljne zaduženosti

Izražen značaj postižu dugoročni bilansi tokova spoljnotrgovinske razmjene.

Tabela 4 - Odrednice spoljnotrgovinskih eksportno-importnih kretanja (Milioni evra)

\begin{tabular}{|c|c|r|r|r|r|r|}
\hline R. br. & Elementi & \multicolumn{1}{c|}{2001.} & \multicolumn{1}{c|}{2006.} & \multicolumn{1}{c|}{2011.} & \multicolumn{1}{c|}{2017.} & \multicolumn{1}{c|}{ Rast (\%) } \\
\hline 1. & Izvoz robe & $1.922,2$ & $5.102,5$ & $8.441,4$ & $15.047,1$ & 13,73 \\
\hline 2. & Uvoz robe & $4.759,2$ & $10.460,7$ & $14.250,0$ & $19.418,6$ & 9,19 \\
\hline 3. & Odnos (\%) & 40,39 & 48,78 & 59,24 & 77,49 & 4,16 \\
\hline 4. & Otvorenost & - & 77,4 & 82,7 & 115,7 & 3,69 \\
\hline
\end{tabular}

Izvor: Ministarstvo finansija Republike Srbije [decembar, 2017], „Bilten javnih finansija“, Beograd, str. 15-16.

Napomena: Robna trgovinska razmjena obuhvata razmjenu pravnih lica i preduzetnika. Stepen otvorenosti ekonomije predstavlja učešće kumulativa izvoza i uvoza roba i usluga u BDP-u. Pokazatelj otvorenosti za 2017. odnosi se samo na prva tri kvartala.

Sagledava se trend porasta pokrivenosti uvoza izvozom proizvoda (roba). Međutim i dalje postoji obilježje kontinuiranog deficita spoljnotrovinske razmjene. Bitan činilac spoljnotrgovinskih odnosa sačinjava robna razmjena kao determinanta trgovinskog bilansa. Elemenat spoljnoekonomskih relacija su i usluge u savremenim uslovima (proizvodnih činilaca rada, kapitala, privrednih grana, djelatnosti). [2; 567] Sa aspekta sadašnjeg vremena dolazi do favorizovanja strategija otvorene privrede. Može se tumačiti u novijem periodu da postoji previsoki stepen otvorenosti privrede. 


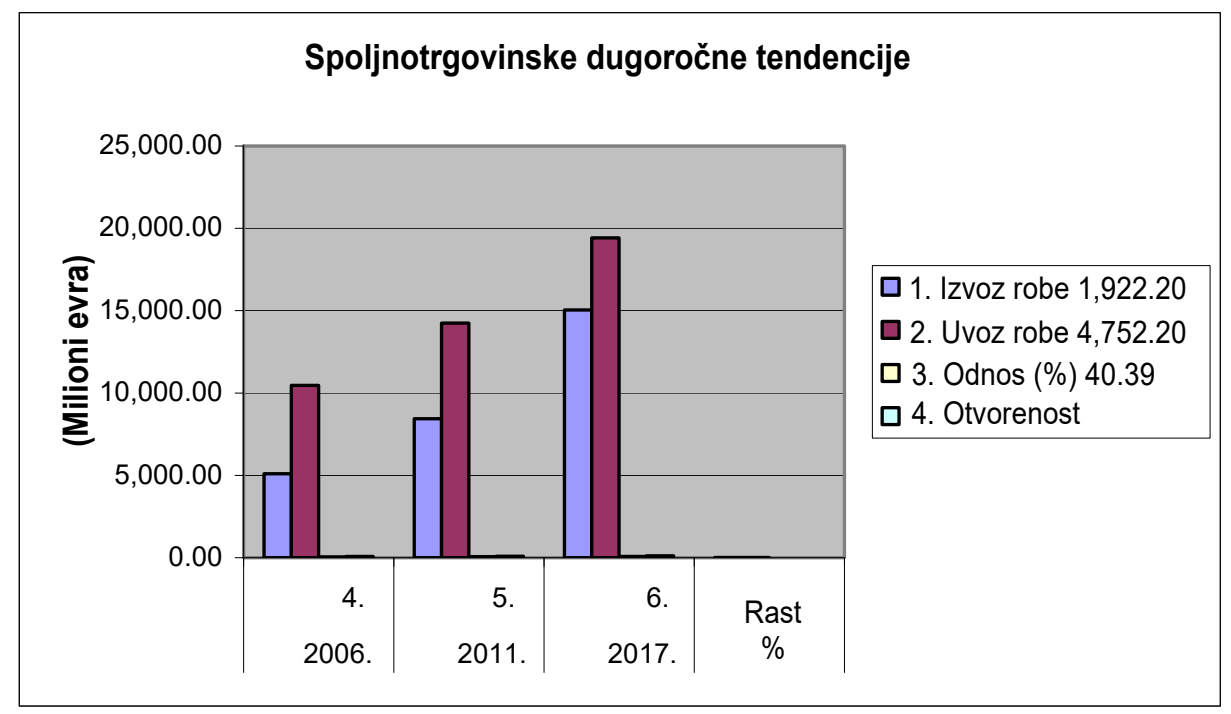

Grafikon 4 - Dosadašnji trendovi spoljnotrgovinskih transakcija

Sa aspekta problematike prikazaćemo stanje i tok pojedinih deviznih kategorija.

Tabela 5 - Parametri, veličine deviznih rezervi NBS i devizne štednje (Milioni evra)

\begin{tabular}{|c|l|r|r|r|r|r|}
\hline R. br. & Elementi & \multicolumn{1}{c|}{2001.} & \multicolumn{1}{c|}{2006.} & \multicolumn{1}{c|}{2011.} & \multicolumn{1}{c|}{2017.} & \multicolumn{1}{c|}{ Rast (\%) } \\
\hline 1. & Rezerve & 1.325 & 9.020 & 12.058 & 9.961 & 13,44 \\
\hline 2. & Štednja & 330 & 3.346 & 7.611 & 9.373 & 33,58 \\
\hline
\end{tabular}

Izvor: Isto, str. 15-16.

Kristališe se dugoročni trend porasta finansijskih deviznih sredstava: rezervi i štednje. Postoji fluktuacija kod mase rezervi, dok je rastući volumen štednje. 


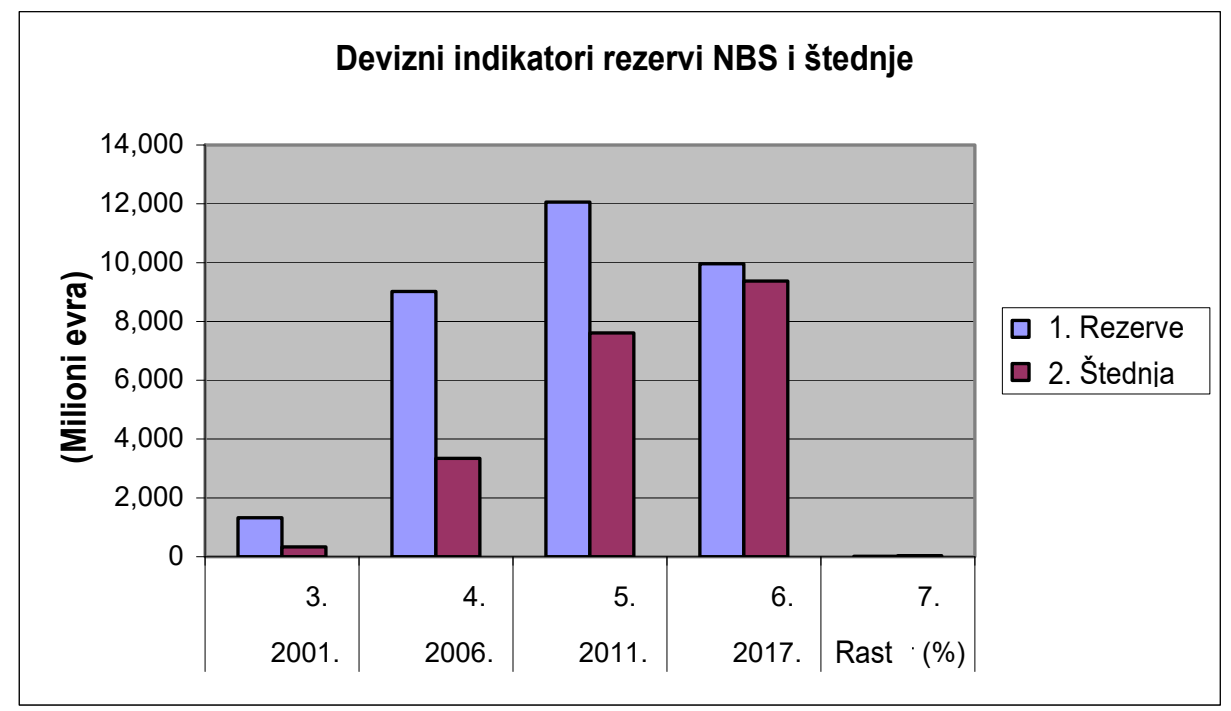

Grafikon 5 - Finansijski, devizni tokovi volumena, sredstava

Relevantni su i indikatori ostvarenih prihoda od procesa privatizovanja [7] ranijih društvenih preduzeća karakterističnih tokom prelaznog, tranzicionog perioda.

Tabela 6 - Realizovani prihodi, od privatizacije društvenih, subjekata (Milioni evra)

\begin{tabular}{|c|l|r|r|r|r|r|}
\hline R. br. & Elementi & 2001. & 2006. & 2011. & 2017. & Rast (\%) \\
\hline 1. & Prihodi & 318,5 & 216,5 & 18,0 & 61,1 & $-10,48$ \\
\hline
\end{tabular}

Izvor: Isto, str. 15-16.

Napomena: Pokazatelj za 2001. nije prikazan i prezentovan je indikator za 2002. godinu

Iskristalisan je opadajući trend nivoa vrednosnih pokazatelja postignutih procesom privatizacije. Najveća reprezentativna vrijednost prihoda dosegnuta je tokom $2003,840,8$ miliona evra. Često se ističe pitanje zakonitosti ovog procesa - društvena imovina koju su stvarale generacije zaposlenih ustupana je u bescjenje i besplatno. Isto tako, sama po sebi aktivnost privatizovanja nije dovoljna za postizanje ekonomske efikasnosti. Ovo dokazuju mnoga propala privatizovana preduzeća. Nužno je postojanje adekvatne upravljačko rukovodeće preduzetničke poslovne strukture. 


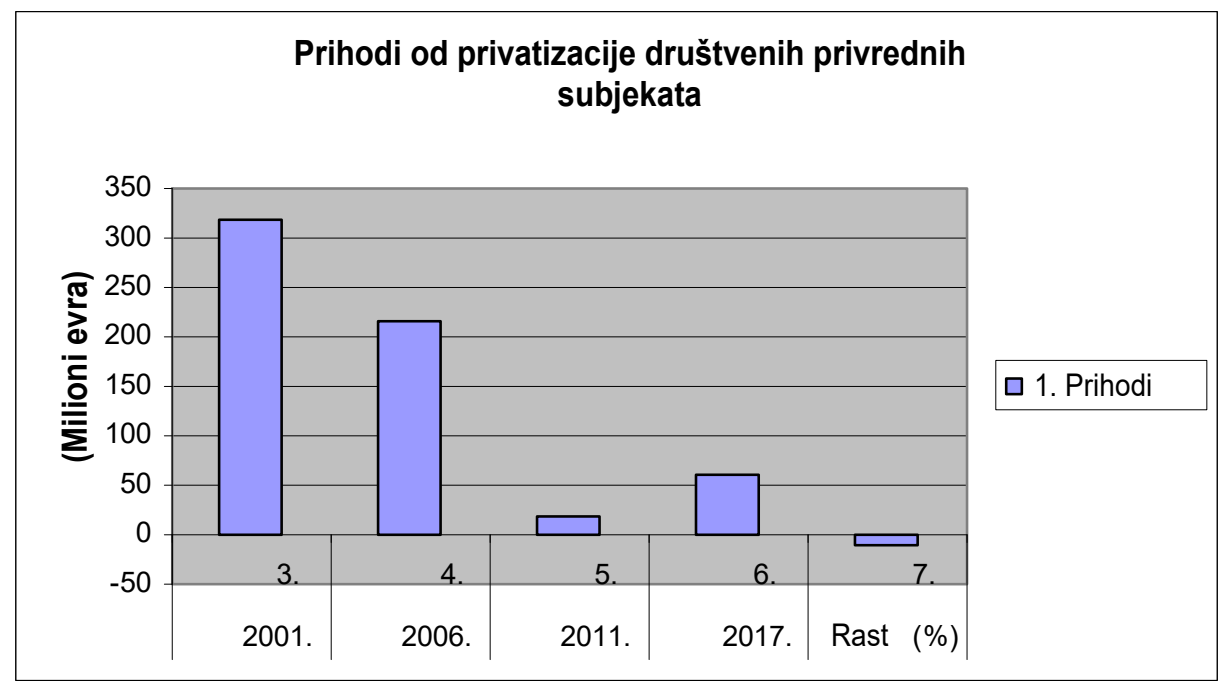

Grafikon 6 - Vrednosni pokazatelji privatizacije

Kretanje deviznih kurseva (cijena valuta) u dugom periodu od posebnog je značaja.

Tabela 7 - Tendencije međusobne vrijednosti relevantnih valuta

\begin{tabular}{|c|l|r|r|r|r|r|}
\hline R. br. & Elementi & \multicolumn{1}{c|}{2001.} & \multicolumn{1}{c|}{2006.} & \multicolumn{1}{c|}{2011.} & \multicolumn{1}{c|}{2017.} & \multicolumn{1}{c|}{ Rast (\%) } \\
\hline 1. & EUR:RSD & 59,71 & 79,00 & 104,64 & 118,47 & 4,36 \\
\hline 2. & Prosjeci & 60,69 & 84,11 & 101,95 & 121,34 & 4,73 \\
\hline
\end{tabular}

Izvor: Isto, str. 15-16.

Napomena: Prosjek perioda za 2001. nije prikazan već postoji pokazatelj za 2002.

Sagledava se dugoročni rast valutnog kursa sa određenim stabilizovanjem u najnovijem periodu. Devizni kurs (sa kamatnom stopom) važan je ekonomski instrumenat. 


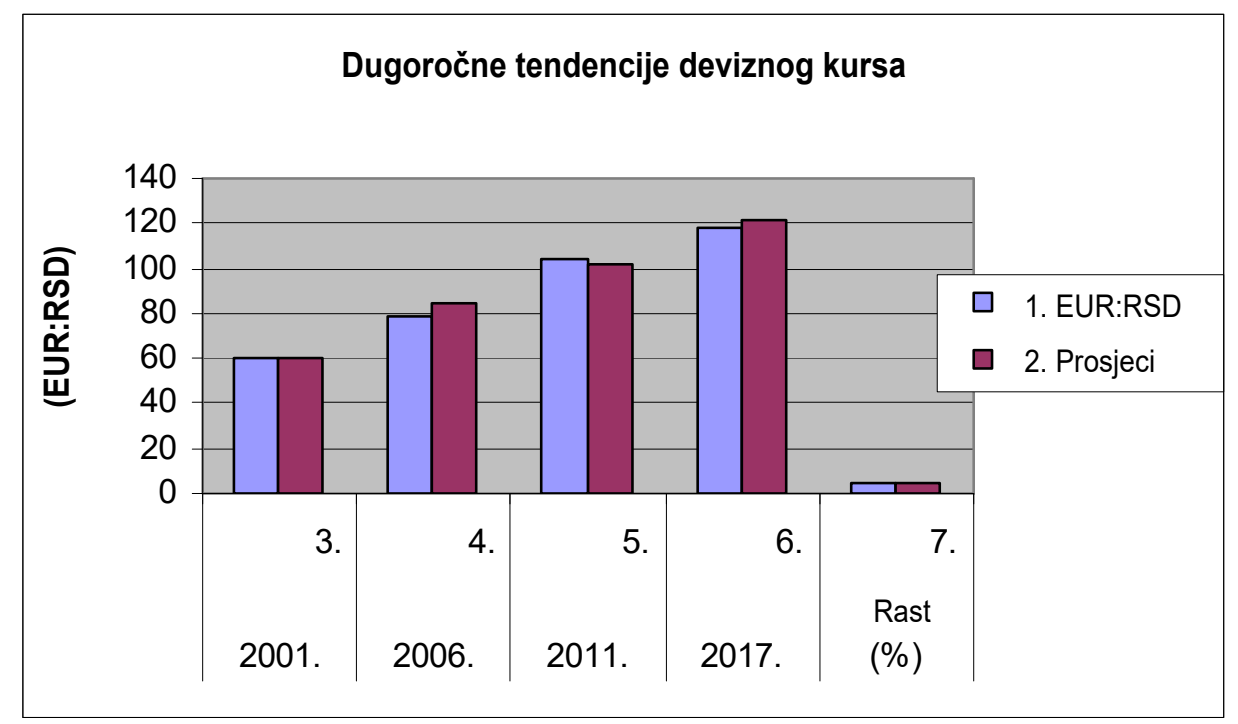

Grafikon 7 - Sagledavanje (ukupnih i prosječnih) dugoročnih, relacija odnosnih valuta

Ekonomske kategorije izražene u valuti evropske zone prikazane su polazeći jedino od postojećih političkih težnji u Srbiji za pristupanje evropskoj integraciji.

\section{Zaključak}

Evropska integracija zemalja osnovana je sa određenim „vizijama, idejama i motivacijom“. Nastojalo se ujedinjavanju Evrope, političkim, ekonomskim i ostalim povezanostima, koje će dovesti do povoljnijih ukupnih učinaka, dinamičnijeg privrednog rasta, zapošljavanja, kretanja kapitala, garantovanja perspektivnije Evrope.

Analogno (u određenom smislu) koncepciji nekadašnjeg socijalističkog samoupravljanja u bivšoj SFR Jugoslaviji koje je bilo potpuno originalno (nigdje drugde primjenjivano u svijetu) [10] tako i „kreatori“ nove i ujedinjene Evrope krenuli su sa originalnim eksperimentom. Pored političke formirana je i ekonomska, monetarna unija velikog obima između zemalja sa izraženim i velikim posebnostima, specifičnostima, neravnomjernostima. Politička, ekonomska i dr. integracija bila je proklamativno osmišljena kao metod za ostvarivanje i intenziviranje društvene „demokratije“, „demokratskih ideja vodilja i ideala“ u evropskom regionu. Ekonomska integracija, tvrdi se, išla je ispred političke i došlo je do protivrječnosti. [13;59-88]

Kriza u Evropskoj uniji i, prvenstveno, Evrozoni traje već duži period. Nagovještaji da Evropa u dogledno vrijeme obnovi i postigne održi značajni ekonomski rast i razvoj praktično nisu sagledivi.

Pored BDP-a postoje i obuhvatniji socijalni pokazatelji i efekti koji su poražavajući za uniju i evrozonu. Učinak evrozone je nepovoljniji od učinaka zemalja koje ne pripadaju evrozoni. Kao model „uspješnosti“ ističe se Njemačka, koja je, isto tako, ostvarila nepo- 
voljne rezultate. [13; 88-109] Stvaranje monovalute pretpostavljalo je i formiranje centralizovane finansijske institucije tj. Evropske centralne banke za cjelokupnu evrozonu. Ova bankarska institucija određuje kamatne stope koje se primjenjuju na ukupnom regionalnom prostoru. Centralna banka npr. može da realizuje i transakcije kupoprodaje deviznih sredstava. Kamatna stopa na višem nivou dovodi do veće potražnje za valutom (evrima) i na ovaj način do višeg deviznog kursa. Centralna bankarska ustanova aktivnostima i mjerama snižavanja kamatnih stopa (i kamata) proširuje pristupačnost kreditnim plasmanima i ovim pospješuje ekonomske aktivnosti i djelatnosti. Navedeno umanjivanje kamatne stope efektuira se u višem kursu, na način da izvoz roba i (ili) usluga postaje konkurentniji (jeftiniji) i demotiviše se i umanjuje konkurentnost uvoza, koji postaje skuplji. Snižavanjem kamatne stope i povišavanjem deviznog kursa, poboljšavaju se ekonomska kretanja. Monetarna politika sačinjava jedan od najbitnijih segmenata, mehanizama i instrumenata javne ekonomske politike. Napuštanje određivanja i kontrolisanja kamatne stope i deviznog kursa za određenu zemlju (konkretno) može dovesti do manje povoljnih ili nepovoljnih učinaka, ekonomski integritet se umanjuje. [13;109-111]

Aktuelna politika u Srbiji izražava stremljenje ka pristupanju Evropskoj integraciji, kao proklamativno dugoročnom, prioritetnom cilju i interesu. Gubi se iz vida perspektiva, kriza u kojoj se nalazi evropska integracija (napuštanjem članstva) i valutna zona (čiji članovi nisu sve zemlje unije), kao i politička i ekonomska dominacija pojedinih država (Njemačke). Pored ovog, u samu evropsku integraciju nije moguće pristupiti bez političkog priznavanja državne nezavisnosti Kosova i Metohije.

\section{Literatura}

[1] Bulatović M. [2011], Ekonomija i demokratija - Držati glavu iznad, Jumedia Mont doo, Podgorica.

[2] Dragutinović D., Filipović M., Cvetanović S. [2005], Teorija privrednog rasta i razvoja, Centar za izdavačku djelatnost Ekonomskog fakulteta u Beogradu, Beograd.

[3] Eling M. [2013], Investicioni fondovi - Inteligentno i racionalno investiranje, Akademska knjiga, Novi Sad.

[4] Majstorović N. [2012], Korupcija - Uzroci, ekspanzija i intervencija, Akademska knjiga, Novi Sad.

[5] Ministarstvo finansija Republike Srbije [decembar, 2017], Bilten javnih finansija, Beograd, str. 15-16.

[6] Milanović B. [2016], Globalna nejednakost - Novi pristup za doba globalizacije, Akademska knjiga, Novi Sad.

[7] Pejanović R. [2015], Tranzicija i nacionalna kultura - Ogledi iz društveno-ekonomske antropologije, Akademska knjiga, Novi Sad.

[8] Piketi T. [2015], Kapital u 21 vijeku, Akademska knjiga, Novi Sad.

[9] Rikalović G. [2002], Dugoročni ekonomski razvoj - Način stvaranja bogatstva, Ekonomski zbornik Srpske akademije nauka i umjetnosti, Knjiga 12, Beograd.

[10] Stojadinović D. [2006], Ekonomski kalendar, Akademska štampa, Zemun.

[11] Štiglic E. Dž [2013], Slobodan pad - Amerika, slobodna tržišta i slom svjetske privrede, Akademska knjiga, Novi Sad.

[12] Štiglic E. Dž [2015], Velika podjela - Društva nejednakosti i šta da radimo sa njima, Akademska knjiga, Novi Sad.

[13] Štiglic E. Dž. [2016], Evro - Kako zajednička valuta ugrožava budućnost Evrope, Akademska knjiga, Novi Sad. 